\title{
New Dramaturgies
}

\author{
Series Editors \\ Cathy Turner \\ Drama Dept. \\ University of Exeter \\ Exeter, United Kingdom
}

Synne Behrndt

Dept. of Community and Performing Arts

University of Winchester

Winchester, United Kingdom 
This series seeks to develop understanding of dramaturgy as a contemporary field, in dialogue with its rich and varied past. The prefix 'new' invites authors to pay attention to the expansion or re-framing of dramaturgy in relation to contemporary contexts, rather than implying a requirement to replace 'old' with 'new', or to offer a programmatic approach to the definition and practice of dramaturgy. The series will comprise two strands: Course texts which encompass fresh and original research insights on key themes related to dramaturgy, at an accessible level for students and non-experts; More specialized work which includes a higher level of theorisation. The books in this series will, for example: look at the dramaturgical implications of new media, globalisation and forms of spectatorship; draw on an 'expanded' use of dramaturgical analysis to examine the relationship between theatrical performance and other disciplines; discuss dramaturgical practice and theory, across a range of perspectives and geographies. Aims of the series: To foster international dialogue and exchange, extending understanding of the complex contexts of dramaturgy and embracing its diversity and scope To examine and deploy dramaturgical thinking as a productive analytical and practical approach to performance criticism as well as performance-making To offer theoretical discussion of dramaturgy as a field To investigate the relationship between idea and form in contemporary practice, including practice-asresearch To discuss emerging areas of contemporary performance practice that produce new dramaturgies or re-contextualise existing approaches To provide English-language texts for teaching dramaturgy in Higher Education To build on existing overviews of dramaturgy and of contemporary performance practice to discuss specific aspects of dramaturgy in detail, applying historical and theoretical rigour.

More information about this series at http://www.springer.com/series/14742 
Peter Eckersall • Helena Grehan • Edward Scheer

\section{New Media Dramaturgy}

Performance, Media and New-Materialism 
Peter Eckersall

The Graduate Center

City University of New York

New York, USA

Edward Scheer

School of the Arts \& Media

University of New South Wales

Sydney, New South Wales, Australia
Helena Grehan

Murdoch University

Perth, Australia

New Dramaturgies

ISBN 978-1-137-55603-5

DOI $10.1057 / 978-1-137-55604-2$

ISBN 978-1-137-55604-2 (eBook)

Library of Congress Control Number: 2017932655

(C) The Editor(s) (if applicable) and The Author(s) 2017

The author(s) has/have asserted their right(s) to be identified as the author(s) of this work in accordance with the Copyright, Designs and Patents Act 1988.

This work is subject to copyright. All rights are solely and exclusively licensed by the Publisher, whether the whole or part of the material is concerned, specifically the rights of translation, reprinting, reuse of illustrations, recitation, broadcasting, reproduction on microfilms or in any other physical way, and transmission or information storage and retrieval, electronic adaptation, computer software, or by similar or dissimilar methodology now known or hereafter developed.

The use of general descriptive names, registered names, trademarks, service marks, etc. in this publication does not imply, even in the absence of a specific statement, that such names are exempt from the relevant protective laws and regulations and therefore free for general use. The publisher, the authors and the editors are safe to assume that the advice and information in this book are believed to be true and accurate at the date of publication. Neither the publisher nor the authors or the editors give a warranty, express or implied, with respect to the material contained herein or for any errors or omissions that may have been made. The publisher remains neutral with regard to jurisdictional claims in published maps and institutional affiliations.

Cover illustration: END. A Two Dogs/Kris Verdonck production. Image @ Reinout Hiel

Printed on acid-free paper

This Palgrave Macmillan imprint is published by Springer Nature

The registered company is Macmillan Publishers Ltd.

The registered company address is: The Campus, 4 Crinan Street, London, Nl 9XW, United Kingdom 


\section{ACKNOWLEDGEMENTS}

This book emerged from a series of discussions between Peter Eckersall, Ed Scheer and Helena Grehan about the discipline of performance studies at the beginning of the twenty-first century and about our various responses to a range of works we encountered along the way. We wanted to find the opportunity to develop a project that was relevant to the discipline and that allowed us to combine our research interests in new media, dramaturgy and spectatorship. After a series of long discussions, NMD was born, and we began to work together to both define and expand the concept as well as to engage with colleagues on the topic at conferences, workshops, symposia, and via our publications. We would like to thank all of those who contributed to the events on this topic over the past few years.

Our research was funded by the Australian Research Council through the award of a Discovery grant on the topic of NMD, and we would like to thank the ARC, as well as our international 'partner investigators' Marin Blažević and Maaike Bleeker. We are grateful to our colleagues Caroline Wake, Denise Varney, Rachel Fensham, Shintarô Fujii, Sara Jansen and Cody Poulton for their assistance at various stages of the project's development. We would also like to acknowledge Murdoch University, UNSW, the University of Melbourne, and CUNY for supporting this research project. They have provided time, space and financial support that has allowed us to meet, run events, and spend valuable time away from the fray for writing. Kris Verdonck also deserves a mention here, as his contributions to the development of our ideas have been significant. We thank him for his boundless creativity, his political provocation, and his sense of 
humour. We would also like to thank the performance makers and artists who joined us for the NMD praxis workshop we ran at UNSW, and thank $\mathrm{Su}$ Goldfish and staff at the Io Myers Studio. Thanks to Performance Space, Sydney for supporting the project and exhibiting Kris Verdonck's Gossip.

Some of the material in this study has appeared in earlier versions in the following publications: Grehan, Helena. 2001. 'TheatreWorks' Desdemona: Fusing Technology and Tradition.' TDR 45(3): 113-125. Grehan, Helena. 2004. 'Questioning the Relationship between Consumption and Exchange: TheatreWorks' Flying Circus Project, December 2000.' Positions East Asia Cultures Critique 12(2): 565-586 - and it has been really valuable to have the opportunity to revisit and reconsider these earlier writings in the context of NMD, some years later. We also acknowledge our entry on 'New Media Dramaturgy' in the Routledge Companion to Dramaturgy, ed. Magda Romanska, 2014, London: Routledge - where some of the arguments developed in this book were first canvassed.

The authors are also very grateful to $T D R$ for permission to reuse their three linked essays on NMD that were published in 2015. Grehan, Helena. 2015. 'Actors, Spectators and Vibrant Objects: Kris Verdonck's ACTOR\#1.' TDR 59(3): 132-139. Eckersall, Peter. 2015. 'Towards a Dramaturgy of Robots and Object-figures.' TDR 59(3): 123-131. Scheer, Edward. 2015. 'Robotics as New Media Dramaturgy. The Case of the Sleepy Robot.' TDR 59(3): 140-149.

Kris Verdonck and A Two Dogs Company, Blast Theory, Hotel Modern, Mari Velonaki, Ed Jansen and Louis-Philippe Demers have all kindly supplied us with images and image permissions. A book on NMD without images would have been a sad book. We thank them for their generosity. We would also like to thank Fujimoto Takayuki, Takatani Shiro, Bubu de la Madelaine, Ong Keng Sen, Lydia Teychenne and Kris Verdonck for their generosity in taking the time to discuss their work with us.

Helena Grehan would like to acknowledge the Dean and staff in the School of Arts at Murdoch University who have been gracious in their support throughout the writing of this book. Particular thanks go to Anne Surma and Sandra Wilson. She would also like to thank her co-authors Peter Eckersall and Ed Scheer for spirited discussion, thoughtful exchanges and for pushing her into the new media landscape. Helena would also like to thank Hans-Willem and Saoirse for their love, tolerance and interest. You make everything meaningful. 
Peter Eckersall would like to thank Helena Grehan and Ed Scheer for their continual inspiration and generosity of spirit. Thanks also for the dramaturgical insights and provocations from David Pledger, Katalin Trencsényi, Alyson Campbell, Anny Mokotow, Rachael Swain, Paul Jackson, Melanie Beddie and Paul Monaghan.

Edward Scheer wishes to express his gratitude to Rosa, Cordy, Nini and Isa, and to Peter and Helena. 'If You Want To Go Fast Go Alone, If You Want To Go Far, Go Together' (unattributed, possibly African origin).

Finally, we would like to thank Alexa Taylor, our research assistant, for assisting with the final stages of the manuscript production. Her eye for detail and breadth of knowledge about the topics, works and ideas covered in the book have been invaluable. 


\section{Contents}

1 Cue Black Shadow Effect: The New Media Dramaturgy Experience

2 The Virtual Machine: Projection in the Theatre

3 From Extreme Light to Total Darkness: The Dramaturgy of Organised Light

4 The Theatre of Atmospheres

5 Robots: Asleep, Awake, Alone, and in Love

6 The Theatrical Superfield: On Soundscapes and Acoustic Dramaturgy

7 XD: Reproducing Technological Experience

8 Play/Pause, FF/Rewind. End. Machine Times, End Times: Theatre, Live Film and Video

9 Post-NMD? 
$\mathrm{x}$ CONTENTS

Bibliography

213

Index

229 


\section{List of Figures}

Fig. 2.1 OR by dumb type 27

Fig. 2.2 HUMINID - ACTOR \#l by Kris Verdonck/A Two Dogs Company, 2010

Fig. 2.3 Johan Leysen in $M$, a reflection by Kris Verdonck/A Two Dogs Company, 2012

Fig. 2.4 KAMP by Hotel Modern, 2010 43

Fig. 2.5 KAMP by Hotel Modern, 2010

Fig. 3.1 OR by dumb type $\quad 65$

Fig. 3.2 OR by dumb type 66

Fig. 4.1 Mass - ACTOR \#1 by Kris Verdonck/A Two Dogs Company, $2010 \quad 85$

Fig. 5.1 The Woman and the Snowman by Mari Velonaki, $2013 \quad 109$

Fig. 5.2 Fish - Bird by Mari Velonaki, Sydney $2014 \quad 112$

Fig. 5.3 Mari Velonaki, Fish - Bird installation, Denmark $2009 \quad 116$

Fig. 5.4 DANCER \#3 by Kris Verdonck/A Two Dogs Company, 2010

Fig. 5.5 Tiller Girls by Louis-Philippe Demers, $2010 \quad 128$

Fig. 6.1 Ryoji Ikeda, superposition, Carriageworks, Sydney $2015 \quad 148$

Fig. 6.2 Ryoji Ikeda, superposition, Carriageworks, Sydney 2015

$\begin{array}{lll}\text { Fig. 7.1 OR by dumb type } & 169\end{array}$

Fig. 7.2 Claire Cage as Karen in Blast Theory's KAREN, 2015

Fig. 7.3 KAREN by Blast Theory, 2015 175

Fig. 8.1 Event for Stage by Tacita Dean, Carriageworks, Sydney $2014 \quad 187$

Fig. 8.2 Event for Stage by Tacita Dean, Carriageworks, Sydney $2014 \quad 192$

Fig. 8.3 Gob Squad, Super Night Shot 199

Fig. 8.4 Gob Squad, Super Night Shot 201 